Tersedia online di: http://ejournal-balitbang.kkp.go.id/index.php/jra

\title{
INDUKSI HORMONAL MATURASI GONAD IKAN GABUS (Channa striata)
}

\author{
Muhammad Hunaina Fariduddin Ath-thar, Rudhy Gustiano, Irin Iriana Kusmini, \\ Vitas Atmadi Prakoso, dan Fera Permata Putri
}

Balai Riset Perikanan Budidaya Air Tawar dan Penyuluhan Perikanan

(Naskah diterima: 20 Juli 2016; Revisi final: 31 Januari 2017; Disetujui publikasi: 1 Februari 2017)

\begin{abstract}
ABSTRAK
Ikan gabus (Channa striata) merupakan ikan lokal air tawar potensial untuk pengembangan budidaya di Indonesia. Sebagian besar produksi ikan gabus berasal dari tangkapan di alam yang menyebabkan menurunnya populasi ikan gabus. Domestikasi merupakan salah satu solusi dari masalah ini. Dewasa ini, ikan gabus telah dapat dipijahkan baik secara alami maupun buatan. Namun demikian produksi benih yang dihasilkan masih bergantung pada kondisi lingkungan. Tujuan penelitian adalah mendapatkan dosis oodev yang optimal untuk pematangan gonad ikan gabus, pemijahan alami, dan analisis performa pertumbuhan keturunan pertama. Jumlah larva yang dihasilkan dari pemijahan alami ikan gabus pada lingkungan ex situ adalah 1.250-5.000 ekor per induk. Berdasarkan pertambahan diameter dan fase kematangan telur, induksi hormon dengan dosis 1,5 mL/kg menunjukkan hasil terbaik dibandingkan perlakuan lain (perlakuan dosis 0,5 dan $1 \mathrm{~mL} / \mathrm{kg}$ ). Benih ikan gabus hasil pemijahan alami di luar habitat menunjukkan populasi Bogor memberikan performa pertumbuhan mutlak bobot $(1,7 \pm 0,06 \mathrm{~g})$; laju pertumbuhan spesifik $(2,6 \% \pm$ $0,10 \%$; dan sintasan $(86,43 \% \pm 1,32 \%$ lebih baik dibandingkan benih ikan gabus populasi Palembang.
\end{abstract}

\section{KATA KUNCl: ikan gabus; induksi hormon; pemijahan alami; pertumbuhan}

ABSTRACT: Hormonal induction for gonadal maturation of the stripped snakehead, Channa striata. By: Muhammad Hunaina Fariduddin Ath-thar, Rudhy Gustiano, Irin Iriana Kusmini, Vitas Atmadi Prakoso, and Fera Permata Putri

Striped snakehead (Channa striata) is a market potential of local fish in Indonesia. Up to now (to date), the majority of production comes from natural catches. This condition, if continues, can lead to the decline in natural stock. Domestication offers a promising solution to help solvethis problem. So far, natural spawning for seed production has been done succcesfully. However, continuity of fish supply is still very much dependent on environmental factors. The present study aimed to investigate the optimal hormone dosage for inducing gonad maturation, natural spawning and to analyze growth performance of fry resulted from natural spawning. Striped snakehead broodstock from Palembang and Bogor wereinduced with three dosages of oodev (consisted of Pregnant Mare's Serum Gonadotropinand Aromatase Inhibitor) treatment for gonad maturation $(0.5 \mathrm{~mL} / \mathrm{kg} ; 1 \mathrm{~mL} / \mathrm{kg}$ and $1.5 \mathrm{~mL} / \mathrm{kg})$ with three replications. The reproductive parameters as oocyte diameter and development were measured. Striped snakehead werespawned naturally with male and female ratio of 1:1. Growth performance of seed were analyzed for 40 days of rearing. The result showed that oodev enabled to speed up gonad maturation process. Broodstock induced with $1.5 \mathrm{~mL} / \mathrm{kg}$ oodev showed the biggest egg diameter and was significantly different from other treatments $(P<0.05)$. Fry count resulted from natural spawning ranged from 1,250 to $5,000 /$ broodstock. The broodstock from Bogor produced higher total weight gain $(1.7 \pm 0.06$ g) and better specific growth rate $(2.6 \% \pm 0.10 \%$ than that of Palembang as well as survival rate $(86.43 \% \pm 1.32 \%$.

\section{KEYWORDS: striped snakehead; hormonal induction; natural spawning; growth}

\footnotetext{
\# Korespondensi: Balai Riset Perikanan Budidaya Air Tawar dan Penyuluhan Perikanan. Jl. Sempur No. 1, Bogor 16154, Indonesia.

Tel. + (0251) 8313200

E-mail: faridkkp@yahoo.com
} 


\section{PENDAHULUAN}

Ikan gabus (Channa striata) merupakan salah satu ikan budidaya potensial (Gustiano et al., 2015). Beberapa pertimbangan penting suatu komoditas dianggap potensial antara lain adalah bernilai ekonomis tinggi, memiliki pasar prospektif, produksi, dan tingkat konsumsi masyarakat lokal yang tinggi. Ikan gabus merupakan salah satu ikan konsumsi yang digemari di India maupun Asia Tenggara (War \& Altaff, 2011). Ikan gabus juga merupakan ikan yang menarik untuk dibudidayakan karena beberapa faktor antara lain; harga yang tinggi, pertumbuhan relatif cepat, toleransi kepadatan yang tinggi, dan kemampuan airbreathing (Qin \& Fast, 1996).

Nilai ekonomis ikan gabus meliputi harga yang tinggi dan kandungan albumin daging. Harga ikan gabus di Palembang mencapai Rp 55.000,00/kg (PPHP, 2010) dan di Kalimantan Selatan mencapai Rp $60.000,00 / \mathrm{kg}$ (Balitbang Pertanian, 2013). Permintaan ikan gabus semakin meningkat karena selain untuk konsumsi (BPS, 2013), juga digunakan sebagai bahan medis. Kandungan zat albumin pada ikan gabus berfungsi untuk penyembuhan luka dan obat kanker (Yakoob et al., 1992). Konsumsi ikan gabus segar tertinggi adalah Kalimantan Tengah dengan angka konsumsi sebesar 5,21 kg/kapita; sedangkan serapan ikan gabus asin/diawetkan adalah Jawa Barat, sebesar 3.193 ton. Tingkat serapan ikan menggambarkan besarnya pasar yang ada di suatu wilayah.

Sampai saat ini, ketersediaan ikan gabus masih lebih rendah dibandingkan dengan permintaan dan masih didominasi dari hasil tangkapan alam. Sebagai gambaran, volume produksi perikanan tangkap di perairan umum pada tahun 2011 didominasi oleh ikan gabus dengan volume produksi sebesar 36.837 ton $(10,68 \%$. Mengalami peningkatan produksi dari 31.274 ton (2001) menjadi 36.837 ton pada 2011 atau sebesar 2,95\% (Pusdatin KKP, 2013). Nasution (2012) menyatakan bahwa ikan gabus yang tertangkap di alam ukurannya semakin kecil dan jumlahnya semakin sedikit.

Pada tahun 2015 teknologi domestikasi ikan gabus telah dinyatakan berhasil (Anonim, 2015). Namun upaya produksi ikan gabus dalam jumlah besar tidak mudah jika hanya bergantung pada proses pemijahan secara alami. Pemijahan alami dengan aplikasi hormon merupakan alternatif produksi benih dalam jumlah besar.

Ikan gabus merupakan ikan air tawar yang melakukan pemijahan secara alami di awal atau di pertengahan musim penghujan (Wee, 1982). Beberapa penelitian telah dilakukan berkenaan dengan reproduksinya, tetapi induk yang digunakan adalah ikan yang matang gonad dari penangkapan di alam (Paray et al., 2013; Hossain et al., 2008). Beberapa kajian reproduksi ikan gabus di alam antara lain menyatakan bahwa ikan gabus di Waduk Kedongombo memijah dengan perbandingan 1:1, dari 24 individu dengan kisaran panjang total antara 18,5-50,5 cm; kisaran bobot antara 60-1.020 g; dan kisaran bobot gonad antara 2,70-16,02 g diperoleh fekunditas telur sebanyak 2.585-12.880 butir (Kartamihardja, 1994). Di lingkungan alami, pemijahan ikan tidak hanya tergantung pada proses gametogenesis tetapi berkaitan erat dengan perilaku seperti migrasi sebelum memijah, seleksi habitat, aktivitas membangun sarang, musim kawin, dan keberadaan pasangannya. Kondisi psikologis reproduksi dan tingkah laku ikan akan memengaruhi regulasi sistem syaraf dan sistem endokrin (Bromage, 2001). Ikan gabus dapat melakukan pemijahan dua sampai tiga kali dalam satu musim pemijahan (Bijaksana, 2003).

Hormon yang banyak berperan untuk pematangan gonad adalah FSH (FollicleStimulating Hormone). Aplikasi hormonal FSH ini banyak dilakukan dengan PMSG (Pregnant Mare's Serum Gonadotropin). Penggunaan PMSG ini telah dicobakan pada ikan medaka (Oryzias latipes) secara in vitro dengan dosis $100 \mathrm{IU} / \mathrm{mL}$ dan hasilnya dapat memacu produksi estradiol-17ß oleh folikel dan juga meningkatkan produksi estradiol-17ß yang diinduksi oleh testosteron (Nagahama et al., 1991). Penelitian terbaru yang telah dilakukan oleh Putra (2013) yang menggunakan kombinasi hormon PMSG + AD memberikan pengaruh positif pada nilai IGS sebesar $100 \%$ Pada ikan Tor soro juga dilaporkan bahwa pemberian oodev $1 \mathrm{~mL}$ dapat menghasilkan induk ikan Tor soro matang gonad dalam waktu satu minggu dan tingkat kematangan yang terbaik (Farastuti et al., 2016). Penelitian aplikasi hormon PMSG + AD pada ikan gabus telah dilakukan, tetapi belum memberikan hasil yang optimal. Hutagalung et al. (2015) menginduksikan PMSG + AD (oodev) padaikan gabus dan menunjukkan bahwa dosis terbaik adalah $1,25 \mathrm{~mL} / \mathrm{kg}$ dengan nilai rata-rata IHS (Indeks Hepato Somatik) 1,37\% dan IGS (Indeks Gonado Somatik) 3,35\% akan tetapi tidak dilakukan dari fase awal kematangan gonad dan tidak dilakukan pengamatan antar waktu dari awal kematangan gonad.

Faktor yang memengaruhi sistem kontrol reproduksi ikan adalah mekanisme hormonal di dalam tubuh ikan. Mekanisme hormon reproduksi ikan pada musim pemijahan secara umum dikendalikan oleh brain - hypothalamus - pituitary - gonad (Rottmann et al., 1991). Tujuan penelitian adalah mendapatkan dosis hormon oodev yang efektif untuk pematangan gonad ikan gabus, pemijahan alami, dan analisis performa pertumbuhan keturunan pertama. 


\section{BAHAN DAN METODE}

\section{Induksi Oodev untuk Pematangan Telur}

Rancangan penelitian induksi maturasi gonad, serta ovulasi dan pemijahan pada ikan gabus dilakukan menggunakan rancangan acak lengkap. Rancangan penelitian induksi maturasi gonad ikan gabus menggunakan oodev (Laboratorium Reproduksi dan Genetika Organisme Akuatik, IPB) terdiri atas tiga perlakuan dosis dan menggunakan tiga ekor ikan uji untuk tiap perlakuan sebagai ulangan. Dosis oodev yang diuji adalah: 0,5 mL/kg; $1 \mathrm{~mL} / \mathrm{kg}$; dan $1,5 \mathrm{~mL} / \mathrm{kg}$.

Induk yang digunakan mempunyai kisaran bobot $254,91 \pm 156,86 \mathrm{~g}$ dengan kondisi kematangan gonad yang seragam. Penyuntikan dilakukan setiap 30 hari selama dua bulan pematangan gonad. Parameter yang diamati pada penelitian ini adalah perkembangan diameter telur dan histologi gonad. Pertambahan diameter telur (30 butir) diukur dengan menggunakan mikrometer okuler dengan perbesaran 40 kali. Pengukuran/sampling dilakukan setiap 30 hari jarak induksi. Telur diamati perkembangan diameternya dan diamati histologi dikoleksi dengan menggunakan kateter. Pengamatan diameter telur dilakukan pada awal dan akhir penelitian (minggu ke-8). Hasil pengukuran menggunakan lensa okuler $(\mu \mathrm{m})$ dikalikan dengan pembesaran 4 × 10 (40 kali) dan hasil dari perkalian dalam satuan $\mu \mathrm{m}$ dibagi dengan 1.000, maka didapatkan hasil diameter sebenarnya dalam satuan $\mathrm{mm}$. Kondisi telur/gonad yang diinduksi hormon kemudian diperiksa histologinya untuk melihat perkembangan kematangan gonad. Metode histologi yang digunakan adalah teknik fiksasi dengan metode pewarnaan HE (Haematoxylin Eosin).

\section{Pemijahan Alami}

Penelitian dilakukan di Instalasi Plasma Nutfah Cijeruk, Bogor. Induk ikan gabus diperoleh dari hasil tangkapan alam (Danau Parung dan Sungai Musi Palembang) dipelihara di kolam beton (panjang $8 \mathrm{~m}$, lebar $6 \mathrm{~m}$, dan tinggi $1 \mathrm{~m}$ ). Induk yang digunakan adalah induk yang telah dimatangkan dengan hormon oodev $1,5 \mathrm{~mL} / \mathrm{kg}$. Kolam pemijahan dikeringkan selama 3-4 hari; dimasukkan air setinggi $30-50 \mathrm{~cm}$, kemudian satu pasang induk dimasukkan. Bagian atas permukaan air kolam beton diberi tanaman eceng gondok (60\%luas permukaan kolam). Induk ikan gabus diberi pakan berupa anak ikan nila atau anak ikan nilem (ukuran 1$3 \mathrm{~cm}$ ) dan udang air tawar, serta dilatih pakan pelet apung (protein $28-32 \%$ selama satu bulan. Jumlah total pakan yang diberikan setiap hari adalah 3\% dari biomassa total. Pakan diberikan setiap hari dengan frekuensi pemberian pakan sebanyak tiga kali.

Induk ikan gabus yang digunakan pada pemijahan ini sejumlah sembilan ekor jantan rata-rata ukuran panjang total $29,63 \pm 5,05 \mathrm{~cm}$; bobot $218,56 \pm$ $104,02 \mathrm{~g}$; dan sembilan ekor betina panjang total $30,03 \pm 6 \mathrm{~cm}$ bobot; $254,91 \pm 156,86 \mathrm{~g}$. Empat pasang induk berasal dari Palembang dan lima pasang induk berasal dari Bogor.

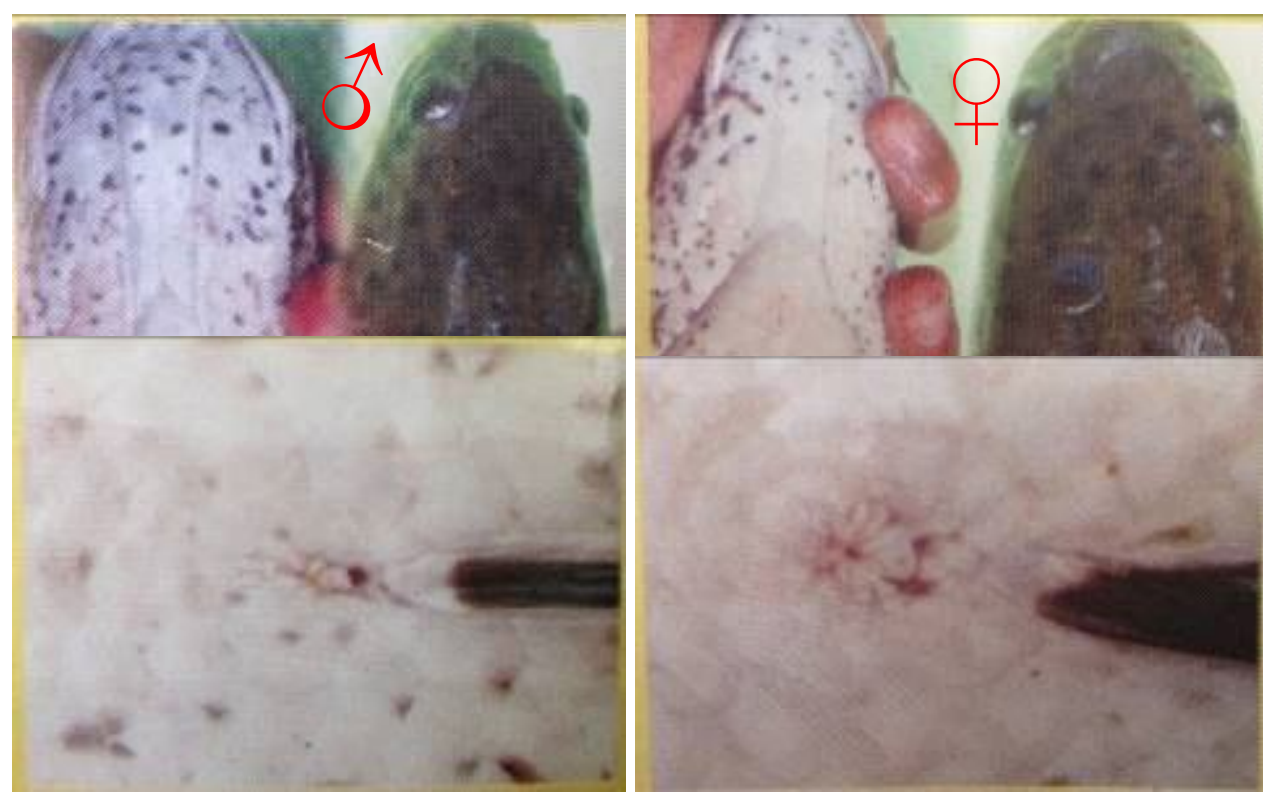

Gambar 1. Perbedaan bentuk kepala (gambar atas) dan urogenital ikan gabus jantan (kiri) dan betina (kanan) (Kusmini et al., 2015)

Figure 1. Head shape and sex differentation of Channa striata broodstock, male (left) and female (right) (Kusmini et al., 2015) 
Pemilihan induk jantan dan betina ikan gabus dapat dibedakan dengan mudah. Caranya dengan melihat tanda-tanda pada tubuh. Jantan ditandai dengan kepala lonjong, warna tubuh lebih gelap, dan betina ditandai dengan kepala membulat, warna tubuh lebih terang (Gambar 1). Ciri-ciri visual pada ikan gabus yang sudah matang gonad adalah induk jantan yang matang ditandai dengan adanya titik pada lubang kelamin yang agak kemerahan dan apabila ditekan keluar cairan bening. Induk betina yang matang gonad ditandai dengan bagian perut membesar (buncit) lembek dan lubang kelamin kemerah-merahan (Gambar 2).
Ketinggian air kolam selama pemijahan pada awal $30 \mathrm{~cm}$ dinaikkan menjadi $50 \mathrm{~cm}$ pada minggu pertama, kemudian diturunkan sekitar $40 \mathrm{~cm}$ pada dua minggu selanjutnya; sebagai perangsang pemijahan, eceng gondok yang berfungsi sebagai substrat pemijahan dimasukkan hingga menutupi 60\%permukaan kolam dan ikan dibiarkan memijah (Gambar 3).

Benih hasil pemijahan untuk pengujian performa pertumbuhan dikoleksi setelah satu minggu proses pemijahan atau ketika benih sudah muncul di permukaan kolam. Koleksi benih dilakukan dengan

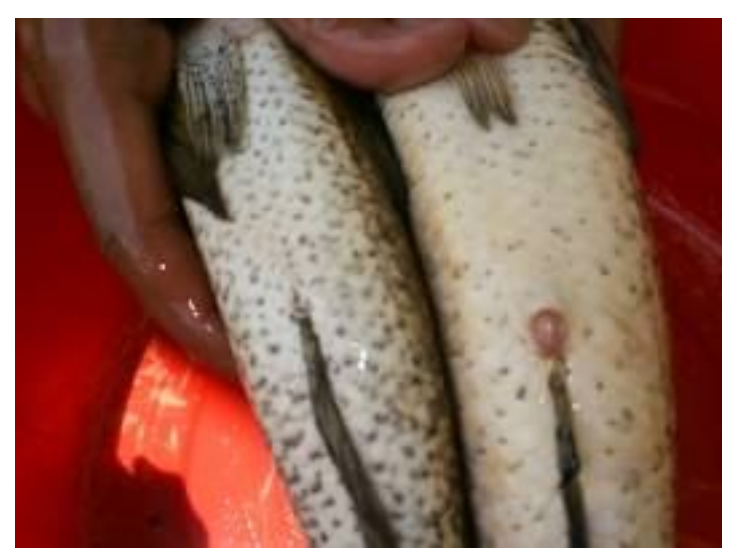

Gambar 2. Induk ikan gabus jantan (kiri) dan betina (kanan) yang telah matang gonad (Kusmini et al., 2015)

Figure 2. Matured male (left) and female (right) of stripped snakehead broodstock (Kusmini et al., 2015)

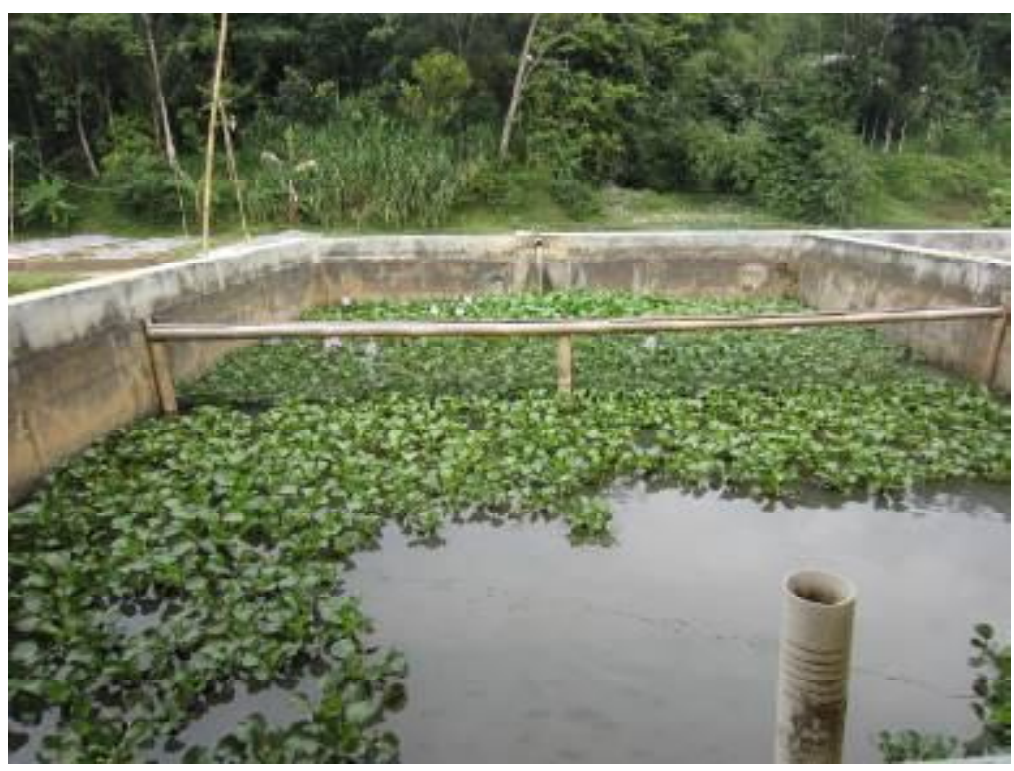

Gambar 3. Kolam untuk pemijahan ikan gabus

Figure 3. Stripped snakehead spawning pond 
memanen total seluruh benih hasil pemijahan kemudian dihitung jumlahnya.

\section{Performa Pertumbuhan Benih Ikan Gabus Populasi Palembang dan Bogor Hasil Pemijahan di Luar Habitat Asli (Ex Situ)}

Evaluasi keragaan benih ikan gabus menggunakan benih hasil pemijahan alami dari populasi Palembang dan Bogor. Seluruh benih dihitung satu per satu kemudian ditebar ke dalam akuarium $(50 \mathrm{~cm} \times 50 \mathrm{~cm}$ $x 40 \mathrm{~cm}$ ) dengan penebaran 50 ekor/akuarium sebanyak empat ulangan pemeliharaan setiap populasi. Benih ditimbang bobot dan diukur panjangnya sebagai titik pengukuran awal pemeliharaan $\left(T_{0}\right)$. Ukuran tebar awal adalah 4,2 $\pm 0,21 \mathrm{~cm}$. Pakan yang digunakan adalah cacing sutra tiga kali sehari dan dilatih pakan buatan (protein 30\% dengan cara penyapihan menggunakan kombinasi 50\%cacing sutra dan 50\%pakan buatan.

Pengukuran pertumbuhan bobot dan panjang dilakukan setiap sepuluh hari sekali dengan jumlah sampel 20 ekor/ulangan. Bobot diukur menggunakan timbangan digital dengan ketelitian 0,01 g; sedangkan panjang diukur dengan ketelitian 0,1 cm menggunakan penggaris aluminium. Sintasan benih dihitung pada akhir pemeliharaan untuk setiap populasi.

Pengelolaan kualitas air pada media pemeliharaan benih dilakukan dengan penyifonan yang dilakukan setiap hari. Pergantian air dilakukan sebanyak 50\%dari total air pada akuarium pemeliharaan. Parameter kualitas air yang diukur pada penelitian ini meliputi suhu, pH, dan oksigen terlarut/DO (Dissolved Oxygen). Pengukuran dilakukan pada awal, tengah, dan akhir pemeliharaan benih. Pengukuran $\mathrm{pH}$ dilakukan dengan $\mathrm{pH}$ meter dan pengukuran suhu, serta oksigen terlarut menggunakan DO meter.

Parameter yang diamati adalah:

\section{Pertumbuhan Mutlak}

Pertumbuhan mutlak panjang maupun bobot merupakan selisih dari panjang atau bobot akhir dan panjang atau bobot awal pemeliharaan. Pertumbuhan mutlak dihitung dengan rumus:

di mana:

$$
\mathrm{PM}=\mathrm{W}_{\mathrm{t}}-\mathrm{W}_{0}
$$

$\mathrm{PM}=$ pertumbuhan mutlak

$\mathrm{W}_{\mathrm{t}}=$ bobot rata-rata ikan pada saat akhir $(\mathrm{g})$

$\mathrm{W}_{0}=$ bobot rata-rata ikan pada saat awal (g)

\section{Laju Pertumbuhan Harian}

Laju pertumbuhan bobot harian (LPH) dengan mengacu kepada rumus Weatherley \& Gill (1987):

$$
\mathrm{LPH}=\frac{\mathrm{LnW}_{\mathrm{t}}-\mathrm{LnW}_{0}}{\mathrm{t}} \times 100
$$

di mana:

$\mathrm{LPH}=$ laju pertumbuhan harian (\%hari)

$\mathrm{W}_{\mathrm{t}}=$ bo bot rata-rata ikan pada saat akhir $(\mathrm{g})$

$\mathrm{W}_{0}=$ bobot rata-rata ikan pada saat awal $(\mathrm{g})$

$\mathrm{t}=$ lama perlakuan (hari)

\section{Sintasan}

Sintasan larva adalah persentase jumlah larva yang hidup pada akhir pengamatan (lima hari) dibandingkan jumlah larva pada awal pemeliharaan. Sintasan larva dihitung berdasar rumus:

$$
\text { Sintasan larva }(\%)=\frac{N_{t}}{N_{0}} \times 100
$$

di mana:

$\mathrm{Nt}=$ jumlah larva awal pemeliharaan (ekor)

$\mathrm{N}_{0}=$ jumlah larva akhir pemeliharaan (ekor)

\section{Analisis Data}

Data yang telah diperoleh kemudian ditabulasi dan dianalisis menggunakan bantuan program Microsoft Excel 2007 dan SPSS 22. Uji lanjut menggunakan uji Duncan pada taraf kepercayaan $95 \%$

\section{HASIL DAN BAHASAN}

\section{Induksi Oodev untuk Pematangan Telur}

Induksi oodev yang dilakukan terhadap induk ikan gabus berpengaruh terhadap kematangan telur ikan gabus yang ditandai dengan adanya pertambahan diameter telur setelah dilakukan induksi. Induk yang diinduksi oodev sebanyak $1,5 \mathrm{~mL} / \mathrm{kg}$ menghasilkan telur dengan diameter paling besar dan berbeda nyata $(P<0,05)$ dibandingkan dengan telur hasil induksi dengan dosis yang lain (Tabel 1 ).

Coward \& Bromage (1998) menyatakan bahwa fase perkembangan gonad pada ikan Tilapia zilii dibagi menjadi delapan tingkat oosit yang dikelompokkan menjadi empat fase yaitu fase previtelogenik (oogonia, kromatin nukleolar, awal perinukleolar, akhir perinukleolar, dan kortikal alveolar), fase vitelogenesis, fase maturasi, dan fase artretic. Pada Tabel 2 berikut ini ditampilkan fase oosit ikan gabus yang diinduksi oleh hormon oodev berbagai dosis.

Setelah induksi pertama, kondisi gonad yang diinduksi oleh oodev berbagai dosis $(0,5 \mathrm{~mL} / \mathrm{kg} ; 1 \mathrm{~mL} /$ $\mathrm{kg} ; 1,5 \mathrm{~mL} / \mathrm{kg}$ ) berada pada fase prinukleolar/primordial (Gambar 4 dan 5). 
Tabel 1. Diameter telur akhir ikan gabus pada perlakuan induksi dengan oodev dengan dosis berbeda

Table 1. Channa striata final egg diameter induced by different dosages of oodev

\begin{tabular}{ccc}
\hline $\begin{array}{c}\text { Dosis induksi hormon } \\
\text { Hormone induction dosage } \\
(\mathbf{m L} / \mathbf{k g})\end{array}$ & $\begin{array}{c}\text { Pertambahan diameter telur } \\
\text { Egg diameter addition } \\
(\mathbf{m} \mathbf{m})\end{array}$ & $\begin{array}{c}\text { Diameter telur akhir } \\
\text { Final egg diameter } \\
\mathbf{( m m})\end{array}$ \\
\hline 0.5 & $0.12 \pm 0.002^{\mathrm{a}}$ & $0.94 \pm 0.098^{\mathrm{a}}$ \\
1 & $0.18 \pm 0.018^{\mathrm{a}}$ & $1.08 \pm 0.165^{\mathrm{ab}}$ \\
1.5 & $0.38 \pm 0.015^{\mathrm{b}}$ & $1.32 \pm 0.093^{\mathrm{b}}$ \\
\hline
\end{tabular}

Keterangan (Note): $\quad$ Huruf superskrip di belakang nilai standar deviasi pada setiap kolom yang sama menunjukkan berbeda nyata $(P<0,05)$ Different superscript symbol on same column showed significantly differences $(P<0,05))$

Tabel 2. Tingkat oosit ikan gabus yang diinduksi oleh hormon $(0,5 \mathrm{~mL} / \mathrm{kg} ; 1 \mathrm{~mL} / \mathrm{kg} ; 1,5 \mathrm{~mL} / \mathrm{kg})$

Table 2. Stripped snakehead oocyte stage induced with hormone $(0.5 \mathrm{~mL} / \mathrm{kg} ; 1 \mathrm{~mL} / \mathrm{kg} ; 1.5 \mathrm{~mL} / \mathrm{kg})$

\begin{tabular}{|c|c|c|c|}
\hline $\begin{array}{l}\text { Sampel ke- } \\
\text { Sample no. }\end{array}$ & $0.5 \mathrm{~mL} / \mathrm{kg}$ & $1 \mathrm{~mL} / \mathrm{kg}$ & $1.5 \mathrm{~mL} / \mathrm{kg}$ \\
\hline 1 & $\begin{array}{l}\text { Awal perinukloelar } \\
\text { Early prinucleolar }\end{array}$ & $\begin{array}{l}\text { Awal perinukloelar } \\
\text { Early prinucleolar }\end{array}$ & $\begin{array}{l}\text { Awal perinukloelar } \\
\text { Early prinucleolar }\end{array}$ \\
\hline 2 & $\begin{array}{l}\text { Akhir perinukloelar } \\
\text { Late prinucleolar }\end{array}$ & $\begin{array}{l}\text { Akhir perinukloelar } \\
\text { Late prinucleolar }\end{array}$ & $\begin{array}{l}\text { Kortikal alveolar } \\
\text { Cortical alveolar }\end{array}$ \\
\hline 3 & $\begin{array}{l}\text { Kortikal alveolar } \\
\text { Cortical alveolar }\end{array}$ & $\begin{array}{c}\text { Kortikal alveolar } \\
\text { Cortical alveolar }\end{array}$ & $\begin{array}{l}\text { Vitelogenesis } \\
\text { Vitellogenesis }\end{array}$ \\
\hline
\end{tabular}

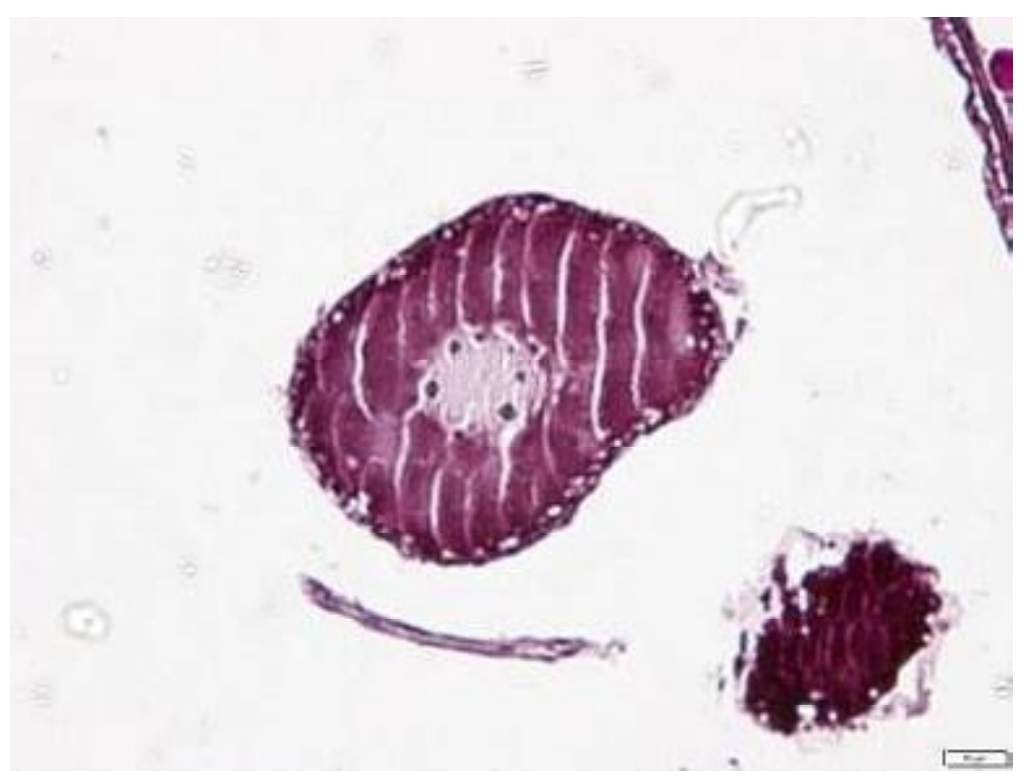

Gambar 4. Awal perinukleolar oosit ikan gabus yang diinduksi oodev sebanyak $1,5 \mathrm{~mL} / \mathrm{kg}$ pada minggu ke-1

Figure 4. Early perinucleolar oocyte stage of stripped snakehead induced with $1.5 \mathrm{~mL} / \mathrm{kg}$ hormone on first week 


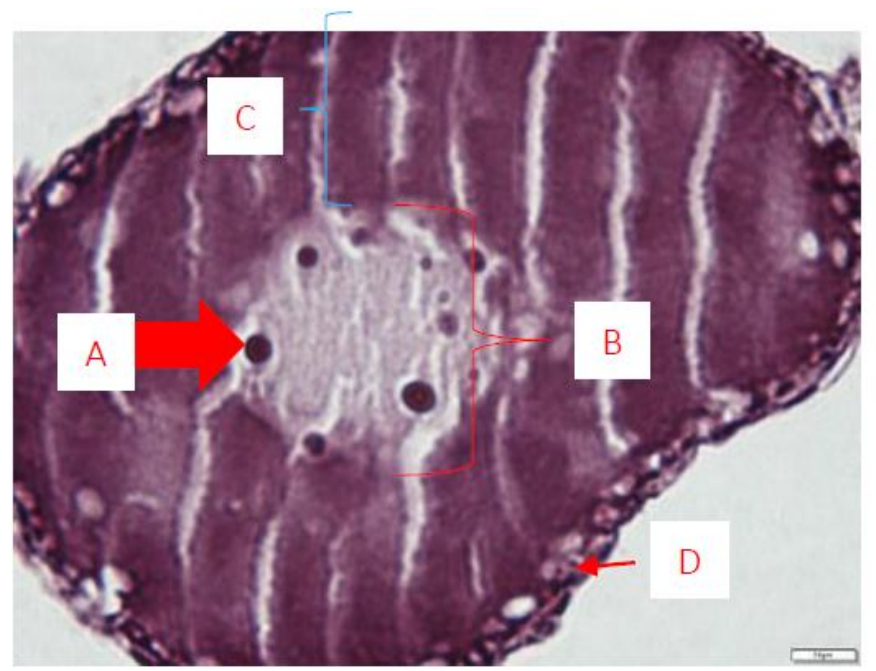

Keterangan: A) Nukleolus, B) nukleus, C) vakuola (stuktur sel vakuola tidak terlihat jelas), D) oosit membrane (sel squamosal-kuboid))

Note: $\quad$ A) Nucleolus, B) nucleus, C) vacuola (unclear vacuola cell structure), D) oocyte membrane (squamosal-cuboid cell))

Gambar 5. Tingkat awal perinukleolar oosit ikan gabus yang diinduksi oodev dosis $1,5 \mathrm{~mL} / \mathrm{kg}$

Figure 5. Early perinucleolar oocyte stage of stripped snakehead induced with $1.5 \mathrm{~mL} / \mathrm{kg}$ hormone

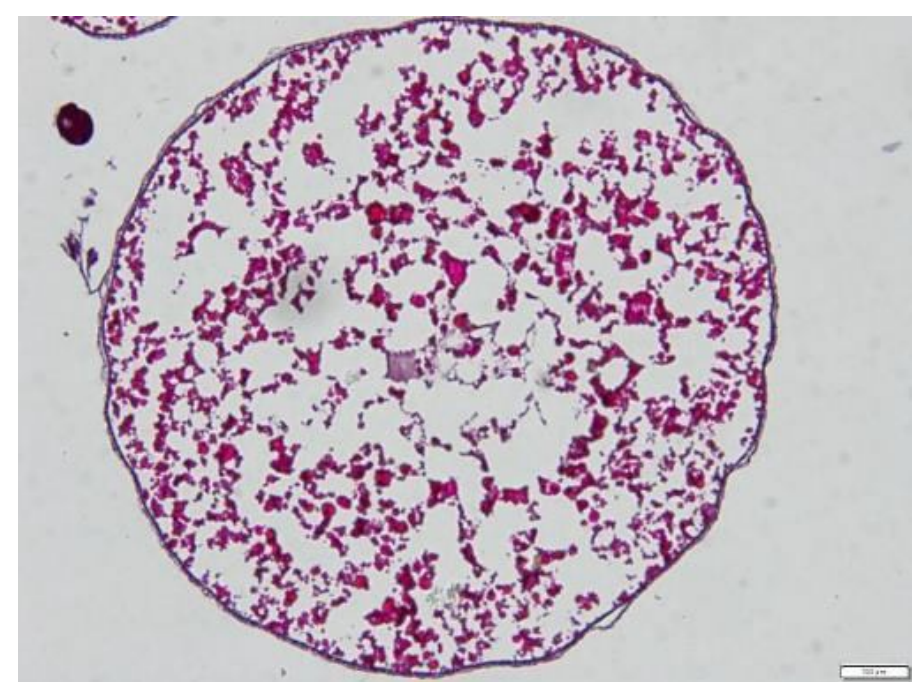

Gambar 6. Tingkat akhir perinukleolar oosit ikan gabus yang diinduksi oodev dosis $1 \mathrm{~mL} / \mathrm{kg}$

Figure 6. Late perinucleolar oocyte stage of stripped snakehead induced with $1 \mathrm{~mL} / \mathrm{kg}$ hormone

Pada pengambilan sampel selanjutnya (minggu ke-5) diketahui kondisi gonad telur ikan gabus yang diinduksi oodev 0,5 dan $1 \mathrm{~mL} / \mathrm{kg}$ memasuki fase primer (Gambar 6) sedangkan gonad telur ikan gabus yang diinduksi oodev $1,5 \mathrm{~mL} / \mathrm{kg}$ sudah memasuki fase sekunder (Gambar 7). Pada fase ini sudah terbentuk vakuola, semakin besar ukuran vakuola maka semakin tinggi tingkat kematangan telur.
Pada pengambilan sampel terakhir (minggu ke-8) diketahui gonad ikan gabus yang diinduksi oodev 1,5 $\mathrm{mL} / \mathrm{kg}$ sudah memasuki fase vitelogenesis (Gambar 8). Fase ini ditandai vakuola yang membesar dan cenderung seragam.

\section{Pemijahan Alami}

Pemijahan terjadi sebanyak tiga kali dan terjadi pada musim penghujan atau ketika terjadi penurunan 


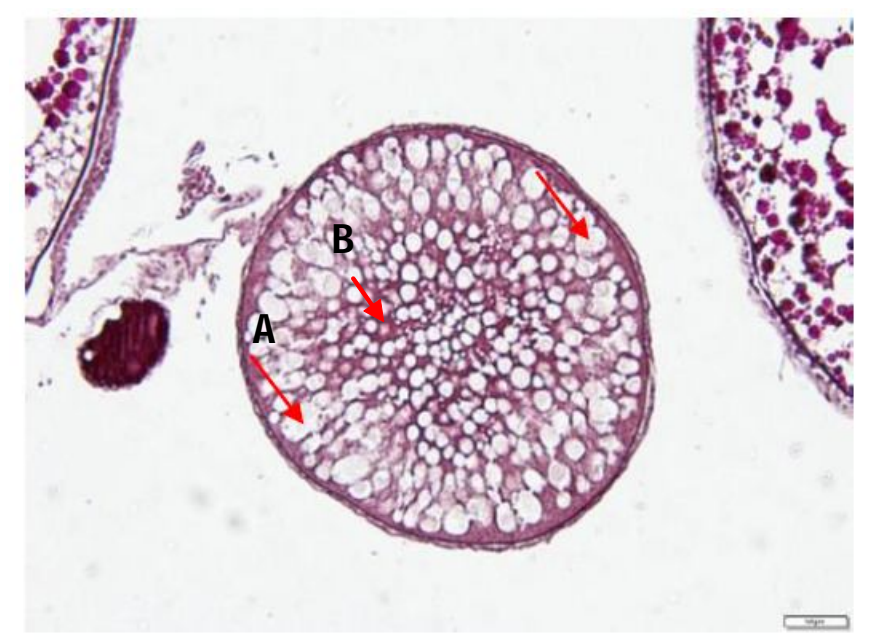

Gambar 7. Tingkat kortical alveolar oosit ikan gabus yang diinduksi oodev 1,5 $\mathrm{mL} / \mathrm{kg}$ (A: vakuola, B: nukleolus) minggu keempat

Figure 7. Cortical alveolar oocyte stage of stripped snakehead induced with $1.5 \mathrm{~mL} /$ $\mathrm{kg}$ hormone (A. vacuola, B. nucleolus) at fourth week

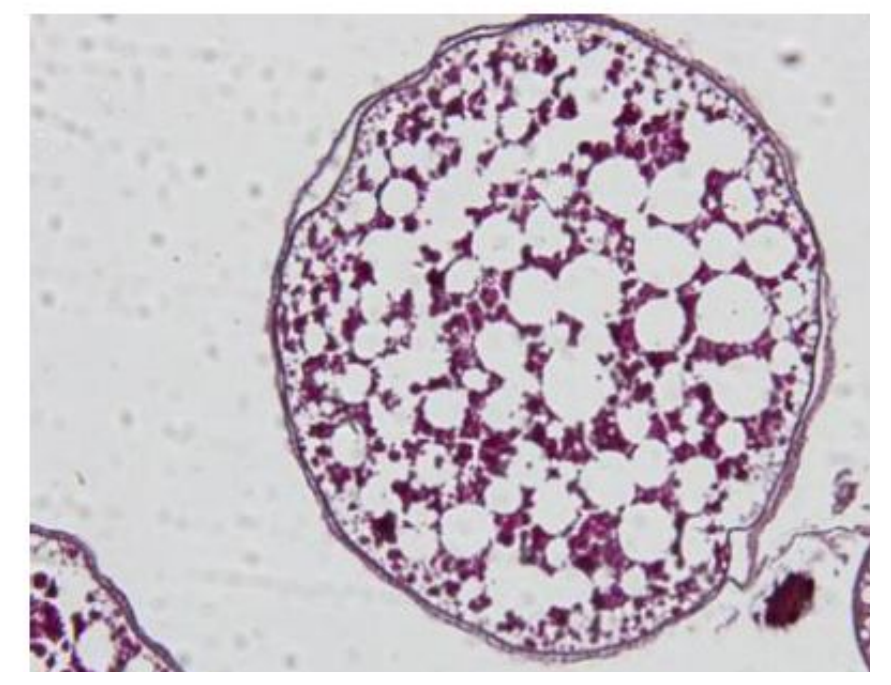

Gambar 8. Vitelogenesis oosit ikan gabus yang diinduksi oodev $1,5 \mathrm{~mL} / \mathrm{kg}$

Figure 8. Vitelogenesis oocyte stage of stripped snakehead induced with $1.5 \mathrm{~mL} / \mathrm{kg}$ hormone

pH. Interval antar pemijahan adalah satu bulan. Kondisi telur ikan gabus satu bulan (Tabel 3) setelah pemijahan telah memasuki kondisi matang ditandai dengan telur gabus yang sudah memasuki diameter kematangan telur $(1,33 \mathrm{~cm})$. Jumlah larva yang dihasilkan setiap pemijahan berkisar antara 1.250-5.000 ekor per induk (Tabel 3).

\section{Performa Pertumbuhan Benih Ikan Gabus Populasi Palembang dan Bogor Hasil Pemijahan Alami di Luar Habitat Asli (Ex Situ)}

Gambar 9 dan 10 menunjukkan grafik pertumbuhan sampai dengan 50 hari pemeliharaan. Laju pertumbuhan benih meningkat dengan kecepatan antar populasi yang relatif sama dan membentuk pola yang sama pada semua populasi.

Ikan gabus dari sumber genetik Bogor menunjukkan pertumbuhan panjang mutlak $(2,3 \pm$ $0,32) \mathrm{cm}$ dan pertumbuhan bobot mutlak $(1,7 \pm 0,06)$ $g$ yang lebih tinggi dibandingkan dengan populasi Palembang (Tabel 4). Sementara itu, laju pertumbuhan harian bobot dan panjang tidak berbeda nyata antar sumber genetik. Laju pertumbuhan spesifik menunjukkan perbedaan nyata, di mana sumber genetik Bogor lebih baik $(2,6 \pm 0,10 \%$ dan berbeda nyata dibandingkan dengan populasi Palembang $(2,4$ $\pm 0,05 \%$. 
Tabel 3. Waktu pemijahan dan jumlah larva yang dihasilkan pada pemijahan alami ikan gabus

Table 3. Spawning time and larvae number resulted from natural spawning of snakehead

\begin{tabular}{ccc}
\hline $\begin{array}{c}\text { Tanggal } \\
\text { Date }\end{array}$ & $\begin{array}{c}\text { Populasi } \\
\text { Population }\end{array}$ & $\begin{array}{c}\text { Jumlah larva hasil pemijahan } \\
\text { Larvae number resulted from spawning }\end{array}$ \\
\hline 11 Februari 2015 & Palembang dan Bogor & Bogor: 5.000 ekor \\
11 February 2015 & Palembang and Bogor & Bogor: 5,000 larvae \\
7-10 Oktober 2015 & Palembang & Tidak tercatat* \\
7-10 October 2015 & & Unrecorded \\
18 Oktober 2015 & Palembang & 1.250 ekor \\
18 October 2015 & & 1,250 larvae \\
\hline Teterangan & & *Terjadi kematian massal sebelum pengamatan jumlan (Mass
\end{tabular}

Keterangan (Note): $\quad *$ Terjadi kematian massal sebelum pengamatan jumlah (Mass mortality evidence before observation)

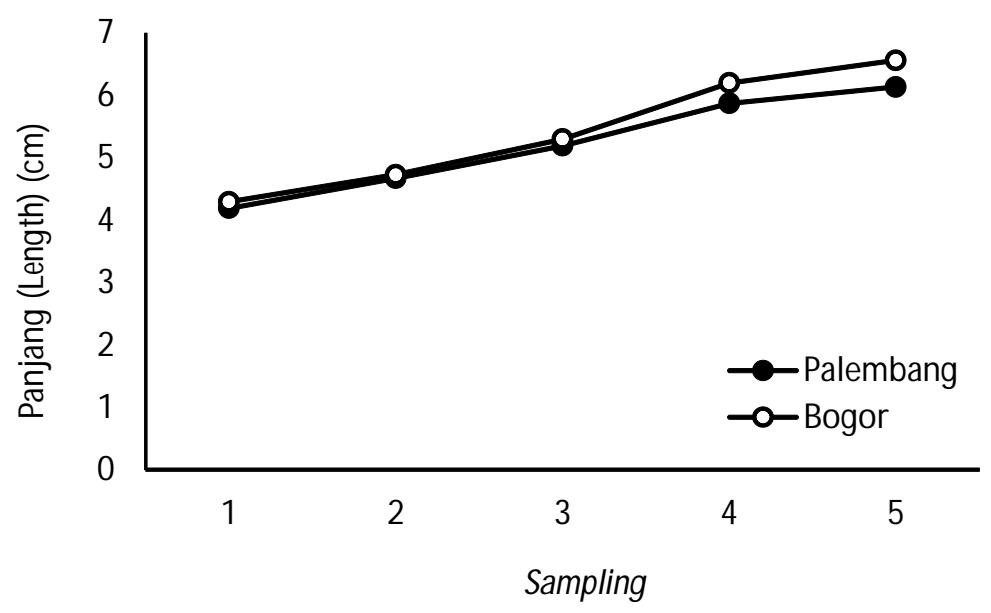

Gambar 9. Pertumbuhan panjang antar waktu benih ikan gabus populasi Bogor dan Palembang selama 50 hari pemeliharaan

Figure 9. Growth performance of length for stripped snakehead from Bogor and Palembang on 50 days rearing

Sintasan benih ikan gabus populasi Bogor lebih tinggi $(P<0,05)$ dibandingkan ikan gabus populasi Palembang (Tabel 4). Hal ini menunjukkan kemampuan beradaptasi ikan gabus pada lingkungan pemeliharaan. Strategi adaptasi suatu populasi terhadap lingkungannya dipengaruhi oleh faktor genetik yaitu keragaman genetik dan keunggulan fenotipe masingmasing tetua yang diwariskan pada keturunannya. Populasi dengan keragaman genetik yang tinggi memiliki peluang hidup yang lebih tinggi, karena banyak alternatif gen atau kombinasi gen yang tersedia untuk merespons perubahan kondisi lingkungan yang dihadapi (Dunham, 2004).

Berdasarkan analisis genetik ikan gabus yang dilaporkan oleh Gustiano et al. (2013) menunjukkan bahwa sumber genetik Jawa memiliki polimorfisme dan heterozigositas $(83,33 \%$ dan 0,3655$)$ lebih tinggi dibandingkan sumber genetik asal Sumatera $(69,44 \%$ dan 0,2811). Interaksi antara variasi genetik dan lingkungan diduga memengaruhi performa fenotipe dari potensi genetik yang baik untuk mendapatkan hasil yang optimal. Apabila potensi genetik didukung oleh lingkungan yang sesuai maka akan terekspresi secara maksimal dan menghasilkan fenotipe yang maksimal pula. Pada kondisi yang optimal kemampuan metabolisme tubuh akan berjalan secara optimal sehingga pertumbuhan dan respons stres berjalan dengan baik. Variasi lingkungan memegang peranan penting dalam memunculkan fenotipe kuantitatif (Tave, 1993). Interaksi genetik dan lingkungan ini timbul karena adanya beberapa alel yang diekspresikan secara berkala dalam lingkungan tertentu (Dunham, 2004).

Dosis oodev yang digunakan pada pematangan ikan gabus ini lebih tinggi jika dibandingkan dengan dosis 


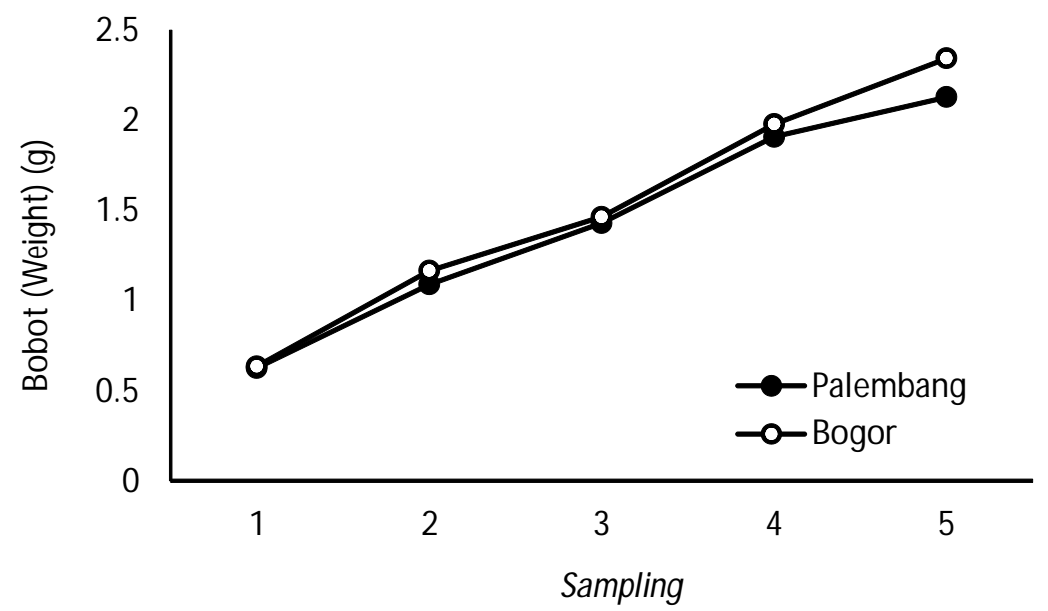

Gambar 10. Pertumbuhan bobot antar waktu benih ikan gabus populasi Bogor dan Palembang selama 50 hari pemeliharaan

Figure 10. Growth performance of weight for stripped snakehead from Bogor and Palembang on 50 days rearing

Tabel 4. Pertumbuhan mutlak, laju pertumbuhan harian, dan laju pertumbuhan spesifik benih ikan gabus populasi Bogor dan Palembang selama 50 hari pemeliharaan

Table 4. Total growth, daily growth rate, and specific growth rate of of stripped snakehead from Bogor and Palembang on 50 days rearing

\begin{tabular}{|c|c|c|c|c|c|c|}
\hline $\begin{array}{l}\text { Populasi } \\
\text { Population }\end{array}$ & $\begin{array}{l}\text { Pertumbuhan } \\
\text { mutlak } \\
\text { panjang } \\
\text { Total length } \\
\text { growth } \\
\text { (cm) }\end{array}$ & $\begin{array}{l}\text { Pertumbuhan } \\
\text { mutlak } \\
\text { bobot } \\
\text { Total weight } \\
\text { growth } \\
\text { (g) }\end{array}$ & $\begin{array}{c}\text { Laju } \\
\text { pertumbuhan } \\
\text { harian panjang } \\
\text { (cm/hari) } \\
\text { Daily length } \\
\text { growth rate } \\
\text { (cm/days) }\end{array}$ & $\begin{array}{c}\text { Laju } \\
\text { pertumbuhan } \\
\text { harian bobot } \\
\text { (g/hari) } \\
\text { Daily weight } \\
\text { growth } \\
\text { rate (g/days) }\end{array}$ & $\begin{array}{c}\text { Laju } \\
\text { pertumbuhan } \\
\text { spesifik } \\
\text { Specific } \\
\text { growth rate } \\
\% \%\end{array}$ & $\begin{array}{c}\text { Sintasan } \\
\text { Survival rate } \\
(\%)\end{array}$ \\
\hline Palembang & $1.6 \pm 0.29^{a}$ & $1.5 \pm 0.47^{\mathrm{a}}$ & $0.03 \pm 0.005^{\mathrm{a}}$ & $0.03 \pm 0.009^{a}$ & $2.4 \pm 0.05^{\mathrm{a}}$ & $81.56 \pm 2.87$ \\
\hline Bogor & $2.3 \pm 0.32^{b}$ & $1.7 \pm 0.06^{b}$ & $0.04 \pm 0.006^{\mathrm{a}}$ & $0.03 \pm 0.001^{\mathrm{a}}$ & $2.6 \pm 0.10^{b}$ & $86.43 \pm 1.32$ \\
\hline
\end{tabular}

Keterangan (Note): Huruf superskrip yang berbeda di belakang nilai standar deviasi pada setiap kolom menunjukkan berbeda nyata $(P<0,05)$ (Different superscript symbol onsame column showed significantly differences $(P<0,05))$

oodev yang dipakai pada ikan Tor soro (Farastuti et al., 2016) dan ikan belut (Putra, 2013). Tingkat kematangan oosit ikan gabus pada penelitian ini terlihat lebih rendah dibandingkan hasil penelitian induksi oodev pada ikan gabus oleh Hutagalung et al. (2015), tetapi pada penelitian tersebut tidak diketahui fase awal induksi dan hanya dilakukan pengamatan selama 72 jam.

\section{KESIMPULAN}

Induksi hormon oodev dengan dosis $1,5 \mathrm{~mL} / \mathrm{kg}$ ikan dapat memacu kematangan gonad sampai dengan fase vitelogenesis dan menunjukkan hasil terbaik dibandingkan perlakuan Iain. Jumlah larva yang dihasilkan dari pemijahan alami ikan gabus pada lingkungan ex situ adalah 1.250-5.000 ekor. Benih ikan gabus hasil pemijahan di luar habitat asli (ex situ) dari populasi Bogor menunjukkan performa pertumbuhan dan sintasan lebih tinggi dibandingkan benih ikan gabus populasi Palembang.

\section{UCAPAN TERIMA KASIH}

Tim peneliti mengucapkan terima kasih kepada Deni Irawan, Bambang Priadi, Dedi, dan Sri Sundari atas bantuan teknis yang diberikan selama kegiatan penelitian. Penelitian ini dibiayai oleh DIPA Tahun 2015 Balai Penelitian dan Pengembangan Budidaya Air Tawar, Bogor. 


\section{DAFTAR ACUAN}

Anonim. (2015). Keputusan Menteri Kelautan dan Perikanan Republik Indonesia Nomor 18/KEPMENKP/2015 tentang Pelepasan ikan gabus Haruan. Kementerian Kelautan Perikanan.

Badan Penelitian dan Pengembangan Pertanian [Balitbang Pertanian]. (2013). Agroinovasi: ikan gabus di kancah nasional. Sinar tani edisi 25. Kementerian Pertanian.

Badan Pusat Statistik [BPS]. (2013). Survey sosial ekonomi 2013: Preferensi Ikan Rumah Tangga Nasional. Jakarta.

Bijaksana, U. (2003). Ikan gabus, Channa sriata Blkr. salah satu potensi komoditas budidaya. (1st ed.). Jurusan Budidaya Perairan, Universitas Lambung Mangkurat. Banjarbaru, $117 \mathrm{hlm}$.

Bromage, N.R. (2001). Broodstock management and seed quality - general consideration. In Bromage, N.R., \& Roberts, R.J. (Eds.), Broodstock management and egg and larval quality. p. 1-24. Scotland: Blackwell Science.

Coward, K., \& Bromage N.R. (1998). Histological classification of oocyte growth and the dynamics of ovarian recrudescence in Tilapia zillii. Journal of Fish Biology, 53, 285-302.

Dunham, R.A. (2004). Aquaculture and fisheries biotechnology: genetic approaches. (2nd Eds.). USA: CABI Publishing Cambridge.

Farastuti, E.R., Gustiano, R., Sudradjat, A.O., Kusmini, I.I., Subagja, J., \& Ath-thar, M.H.F. (2016). Induksi kombinasi hormon terhadap konsentrasi estradiol 17-â dalam plasma darah dan tingkat kebuntingan ikan Tor soro. Prosiding Seminar Ikan 2016 (In review).

Gustiano, R., Kusmini, I.I., Iskandariah, I., Arifin, 0.Z., Huwoyon, G.H., \& Ath-thar, M.H.F. (2013). Analisis ragam genotipe RAPD dan fenotipe truss morfometrik pada tiga populasi ikan gabus. Berita Biologi, 12(3), 325-333.

Gustiano, R., Kusmini, I.I., \& Ath-thar, M.H.F. (2015). Mengenal sumber daya genetik ikan spesifik lokal air tawar Indonesia. (1st ed.). Indonesia: IPB Press.

Hossain, M.K., Latifa, G.A., \& Rahman, M.M. (2008). Observations on induced breeding of snakehead murrel, Channa striatus (Bloch, 1793). International Journal of Sustainable Crop Production, 3, 65-68.

Hutagalung, R.A., Widodo, M.S., \& Faqih, A.R. (2015). Evaluasi aplikasi hormon PMSG (Oodev ${ }^{\circledR}$ ) terhadap indeks hepatosomatik dan gonadosomatik ikan gabus. Jurnal Akuakultur Indonesia, 14, 24-29.
Kartamihardja, E.S. (1994). Biologi reproduksi populasi ikan gabus Channa striata di Waduk Kedungombo. Bulletin Perikanan Darat, 12, 113-119.

Kusmini, I.I., Gustiano, R., Prakoso, V.A., \& Ath-thar, M.H.F. (2015). Budidaya ikan gabus. (1st ed.). Jakarta: Penebar Swadaya.

Nagahama, Y., M atsuhisa, A., Iwamatsu, T., Sakai, N., \& Fukada, S. (1991). A mechanism for the action of pregnant mare serum gonadotropin on aromatase activity in the ovarian follicle of the medaka (Oryzias latipes). Journal of Experimental Zoology, 259, 53-58.

Nasution, Z. (2012). Kelembagaan pengelolaan sumberdaya perikanan "lelang lebak lebung" dan kemiskinan masyarakat nelayan (studi kasus di Kabupaten Ogan Komering Ilir - Sumatera Selatan). Tesis. Sekolah Pascasarjana IPB. Bogor, $162 \mathrm{hlm}$.

Pusat Data dan Informasi Kementerian Kelautan Perikanan [Pusdatin KKP]. (2013). Statistik kelautan dan perikanan 2011. Jakarta: Kementerian Kelautan Perikanan.

Direktorat Jenderal Pengolahan dan Pemasaran Hasil Perikanan [PPHP]. (2010). Warta Perikanan Indonesia: bagusnya ikan gabus. Volume 86. Kementerian Kelautan dan Perikanan. $32 \mathrm{hlm}$.

Paray, B.A., Haniffa, M.A., Manikandaraja, D., \& Milton, M.J. (2013). Breeding behavior and parental care of the induced bred striped murrel (Channa striatus) under captive conditions. Turkish Journal of Fisheries and Aquatic Sciences, 13, 707-711.

Putra, W.A.P. (2013). Induksi maturasi belut sawah (Monopterus albus) secara hormonal. Tesis. Institut Pertanian Bogor.

Qin, J., \& Fast, A.W. (1996). Size and feed dependent cannibalism with juvenile snakehead (Channa striatus). Aquaculture, 144(4), 313-320.

Rottmann, R., Shireman, J.V., \& Chapman, F.A. (1991). Hormonal control of reproduction in fish for induced spawning. SRAC Publication No. 424. United States Departemen of Agriculture.

Tave, D. (1993). Genetics for fish hatchery managers. Connecticut: AVI Publishing Co., Inc.

War, M., \& Altaff, K. (2011). Preliminary studies on the effect of prey length on growth, survival and cannibalism of larval snakehead, (Channa striatus) (Bloch, 1793). Pakistan Journal Zoology, 46, 9-15.

Weatherley, A.H., \& Gill, H.S. (1987). The biology of fish growth. Academic Press, Toronto. Canada, $443 \mathrm{pp}$. 
Induksi hormonal maturasi gonad ikan gabus (Channa striata) (Muhammad Hunaina Fariduddin Ath-thar)

Wee, K.L. (1982). The biology and culture of snakeheads: recent advances in aquaculture. (1st ed.). Colorado: Westview Press.
Yaakob, W.A.A.W., \& Ali, A.B. (1992). Simple method for backyard production of snakehead (Channa striata Bloch) fry. The ICLARM Quarterly, 15, 2223.a 